\title{
$\mathrm{X}$ 線 回折装置の放射線防護
}

\author{
西 健 雄*，山田典一*，南 實太郎*，長谷川圭佑*，三戸 規 生*
}

(1970年3 月24日 受理)

\section{Radiation Protection against X-ray Diffraction Apparatus}

\author{
By Tatsuo NISHI,* Norikazu YAMADA,* Kentaro MINAMI,* \\ Keisuke HASEGAWA* and Norio MITO*
}

For the purpose of radiation protection against X-ray diftraction apparatus, the followings were carried out : (i) Measurements of the exposure rates of the primary and scattered X-rays produced from the apparatus, (ii) Determinations of the sensitivity of many types of surveymeters for the low energy $X$-rays from the apparatus, and (iii) Experiments on the shielding effect of many kinds of materials such as vinyl sheet, rubber, etc..

Exposure rate of about $600 \mathrm{R} / \mathrm{min}$ was observed for the primary X-rays at the sample holder of the apparatus under the normal operation. For the $8 \mathrm{keV} \mathrm{X}$-rays emitted from the apparatus, the readings of an ionization chamber type surveymeter (ICS-101C) which was designed for X-rays were in good agreement with those of the Victoreen r-meter, whereas the readings of the ionization chamber type surveymeter made for $\gamma$-rays indicated about one half of those of the Victoreen $r$-meter. The shielding effects of several materials such as polyethylen,rubber, cotton cloth, etc. were measured. Among them, vinyl sheet had the greatest shielding effect.

Survery technique and assessment of absorbed dose are described in appendix.

\section{I. 序言}

回折用 $\mathrm{X}$ 線装監に利用される X 線は，5〜20 keV 程 度の低いエネルギーをもった特性 X 線が主である。し たかっって，このような X 線を通常の放射線管理に使用 しているサーベイメータを用いて，測定および被嫘評価 を行なうことは困骮である。また試料固定点における利

*日本原子力研究所 大洗研究所 安全管理課：茨城県東茨域郡 大町 (Health Physics and Safety Sec., Oarai Research Establishment. Japan Atomic Energy Research Institute: Oarai-machi, Higashibaraki-gun, Ibaraki-ken)
用 X 線錐の照射率は一般に非常に高く，そのためわず かな取扱い上の不注意によって，局部的な道剩被睡をう けろ危除性が多い。しかし，X線エネルギーが低いので 遮䊖は極めて简単である。このような特改を有するX線 回折萃置の実際的な放射線管理計画や被曝 防讙上の留 意事項などについては小西らにによって述へられている か，実際の照射率の湘定や被瞵線量の評価法については 蜰れていない。

本報告は，(1) X 線回折装置をいろいろな条件で荤転 した坸合の利用線錐の照射率と装置周辺の散乱線による 照射率分布，(2) 低エネルギー X 線に対する通常の放 射線管理用サーベイメータの校正，および（3）身近に 
西 健 雄, 山田典一, 南

あるピニールやボリエチレンなどの低エネルギー X 線 に対する遮敝奻果について調へた結果を報告する。さら にこれらの結果にもとついて，低エネルギー X 線に対 する被曝評価と被曝防讙の检矹をおこなった。

\section{X 線装盟および測定器}

使用した X 楾回析裝置は理学龟機株式会社製 (Model $\mathrm{D}-3 \mathrm{~F}$ ，連続定格 $60 \mathrm{kVp}, 60 \mathrm{~mA}$ ) で，ターゲットとし てクロム $\left(K_{a} ; 5.02 \mathrm{keV}\right)$ と銅 $\left(K_{a} ; 8.04 \mathrm{keV}\right)$ を用い た。X線管球側のッーラースリットはそのままにし，そ の後にあるタイバージェーススリットの幅を実験の目的 によって変えた。標华線量測定に使用した測定器は， Victoreen condenser r-meter (70-A) でチェンバー は, Model 576 と Model 651 である。

\section{III. 測定および結果}

\section{1 次 X楾および散乱線の測定}

距離による1次 X 線の强度変化は，ターゲットとし てクロムと銅を用い，管電压と管龟流をそれぞれ通常の 使用条件である $30 \mathrm{kVp}$ と $8 \mathrm{~mA}$ に固定して測定した。 タイバーシェンススリット (No. 2-4ㅇ)は, $6.5 \mathrm{~mm} \times$ $10.8 \mathrm{~mm}$ で X 線束がチェンバー (Victoreen Model $651)$ の有効経 $(9 \mathrm{~mm} \phi)$ に入るようにして，管球空よ り $40 \mathrm{~cm}$ の距離まで湘定した。

照射率の減弱を X 線管球䓗からの距離の函数として 求めた結果を Fig. 1 に示した。1 次X 線の照射率は夕 イバーシェンススリット出口において，クロムおよび銅 ターゲットでおのおの約 $1,600 \mathrm{R} / \mathrm{min}, 1,000 \mathrm{R} / \mathrm{min} て ゙$ ある。調整および試料交換時の不注意等によって被曝が

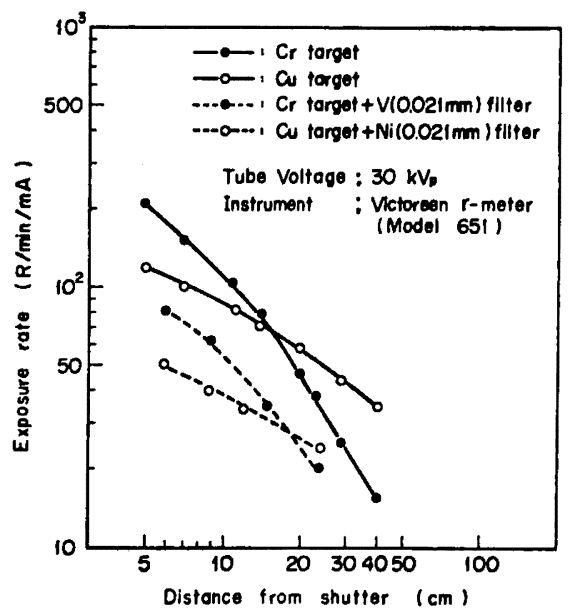

Fig. 1 Attenuation curve against distance
政太郎, 長谷川圭佑, 三尹規生

問題となる試料台位置では, クロムおよび銅ターゲット の場合でおのおの約 $600 \mathrm{R} / \mathrm{min}, 560 \mathrm{R} / \mathrm{min}$ であり, X 線照射中の取扱、には十分な注意が必意である。図中点 線で示してあるのは，ターゲットと組合せて用いられる フィルターを通した場合の照射率の減弱である。これら フィルターを用いることによって，X 線強度は試料台の 位置で，フィルターのない場合と比較してそれぞれ1/2，

Table 1 Calibration factors of various types of survey meters for $8 \mathrm{keV} \mathrm{X}$-rays

\begin{tabular}{|c|c|c|c|}
\hline Survey meter & Reading & $\mid \begin{array}{l}\text { True } \\
\text { dose* rate }\end{array}$ & $\begin{array}{l}\text { Calibration } \\
\text { factor }\end{array}$ \\
\hline $\begin{array}{l}\text { Ionization } \\
\text { chamber } \\
\text { (Aloka. } \\
\text { ICS 101-C) }\end{array}$ & $82.5 \mathrm{mR} / \mathrm{h}$ & $86.3 \mathrm{mR} / \mathrm{h}$ & 1.05 \\
\hline $\begin{array}{l}\text { Ionization } \\
\text { chamber } \\
\left(\begin{array}{c}\text { TEN. } \\
\text { DR-130-1 }\end{array}\right)\end{array}$ & $42 \mathrm{mR} / \mathrm{h}$ & $86.3 \mathrm{mR} / \mathrm{h}$ & 2.06 \\
\hline $\begin{array}{l}\text { GM survey } \\
\text { meter } \\
\text { (Aloka. } \\
\text { TGS-103B) }\end{array}$ & $8 \times 10^{4} \mathrm{cpm}$ & 86. $3 \mathrm{mR} / \mathrm{h}$ & $\begin{array}{l}1.08 \times 10^{-3} \\
\mathrm{mR} / \mathrm{h} / \mathrm{cpm}\end{array}$ \\
\hline $\begin{array}{l}\text { GM survey } \\
\text { meter } \\
\left(\begin{array}{l}\text { TEN. } \\
\text { SM-110) }\end{array}\right.\end{array}$ & $8 \mathrm{mR} / \mathrm{h}$ & $32.4 \mathrm{mR} / \mathrm{h}$ & 4.05 \\
\hline
\end{tabular}

*Measured by victoreen $\mathrm{r}$-meter (Model 576)

35に減少する゙。距䧺による X 線の減弱を示す Fig. 1 から，照射率を $D$, シャッターからの距離を $x$ とする とシャッターから $10 \mathrm{~cm}$ 位まではクロムターゲットでは $D_{C r} \alpha x^{-0.8}$, 銅ターゲットでは $D_{C u} \propto x^{-0.5}$ と, $10 \mathrm{~cm}$ 以上ではクロムおよび銅ターゲットに対しておのおの $D_{C r} \alpha x^{-1.5}, D_{c u} \propto x^{-0.7}$ の成保が近似的に得られ，照 射率が距離の逆二乗で減弱しないのは，ターゲットの形 状やッーラースリットにおける攻乱の影辢なとによるも

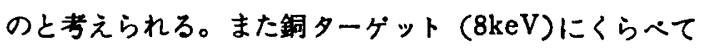
クロムターゲット (5keV) の場合の減弱が大きいのは 空気による吸収の刘果が大きいためである。

散乱線の強さや分布状況は，管電圧，管龟流，試料の 種類および X 線束に対する角度等によって変化すると 考えられるが，ここでは，X 線装置の全ての遮蔽を取外 した状悲にして，銅ターゲットを用いて，通常の使用条 件 $(30 \mathrm{kVp}, 8 \mathrm{~mA})$ で散乱線分布測定を行った。試験試 料は，タンタル $(10 \times 10 \times 2 \mathrm{~mm})$ をアルミニウム試料 支持板 $(35 \mathrm{~mm} \times 50 \mathrm{~mm} \times 1.5 \mathrm{~mm})$ に接着したものを用

*特性 X 楾の強度は管电压を $\mathrm{V}$ ，劯起冤压を Vc とすると $(\mathrm{V}$ $-\mathrm{Vc})^{3 / 2}$ に比例して增加することか知られているか．管电圧

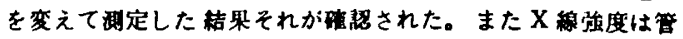
電流に比例して增玑している。 
い，試料の角度を X 線束に対して $45^{\circ}$ にした状悲で揤 定した結果を Fig. 2.に示した。この場合，2次 X 線(回 折 $\mathrm{X}$ 線）も含めていろので, 2 次 $\mathrm{X}$ 線の方向では比較 的照射事が高くなっている，また 1 次 X 線の方向に照 射平が高いのは，試料を透過した後の 1 次 X 線の寄与 と考えられる。

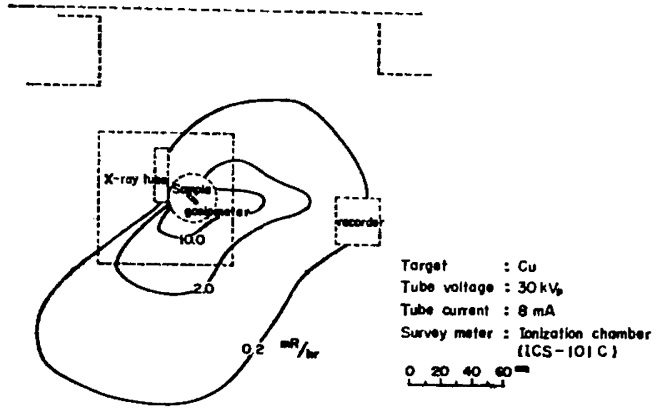

Fig. 2 Distribution of exposure rate due to scattering radiation around the $\mathrm{X}$-ray diffraction apparatus
管球のシールド部分からの漏洩を調へるために，シャ ッターを閉した状悲と開いた状態での漏洩を GM 管型 (端空型) サーベイメータ（TGS-103B型）で剆定し た。シャッターを閉したた状態でも，シャッターやフィル ターのすき間から細いビーム状に放射する漏洩放射線が 多少琶められたが，シャッターを閒いた状態では，特に シャッター部のすき間から多盟の漏洩があった。Goniometer の周囲には，含趴コム弊のカバーが蛇腹式に復っ てあり，その上部はアルミニウムの蓋かしてあるので， ここからの漏洩は全く認められず，遮蔽は完全であっ た。

\section{2. 放射綿管理用サーヘイメータのX楾に対宁る校正}

低エネルギー $\mathrm{X}$ 線の線冝測定は極めて難がしいが， 通常の放射線管理においては，正確さよりもまず手軽に 速く測定できるという点から，手近にある $\gamma$ 線用のサー ヘイメータが使用されるので，銅ターダットを用いて $8 \mathrm{keV}$ の X 線に対する各種サーベイメータの校正を行っ

Table 2 Mass absorption coefficient for various materials and Al equivalent

\begin{tabular}{|l|c|c|c|c|c|}
\hline \multicolumn{1}{|c|}{ Materials } & $\begin{array}{c}\text { Thickness } \\
\left(\mathrm{mg} / \mathrm{cm}^{2}\right)\end{array}$ & $\begin{array}{c}\text { 1st. H. V. L } \\
\left(\mathrm{mg} / \mathrm{cm}^{2}\right)\end{array}$ & $\begin{array}{c}\text { 2nd. H. V. L } \\
\left(\mathrm{mg} / \mathrm{cm}^{2}\right)\end{array}$ & $\begin{array}{c}\text { Mass } \\
\text { absorption } \\
\text { coefficient } \\
\left(\mathrm{cm}^{2} / \mathrm{mg}\right)\end{array}$ & $\begin{array}{c}\text { Al } \\
\text { equivalent } \\
\left(\mathrm{mg} / \mathrm{cm}^{2}\right)\end{array}$ \\
\hline Cellophane paper & 2.02 & 60.6 & 123 & 11.4 & 0.50 \\
\hline Vinyl sheet & 6.58 & 14.2 & 28.8 & 48.0 & 6.75 \\
\hline Polyethylene sheet & 9.31 & 188 & 373 & 3.70 & 0.63 \\
\hline Cotton glove & 12.9 & 92.8 & 194 & 7.50 & 2.40 \\
\hline Surgical glove (rubber) & 18.1 & 110 & 220 & 6.50 & 2.39 \\
\hline Yellow robe (cotton) & 23.6 & 104 & 205 & 6.70 & 4.25 \\
\hline Plastic board & 226 & 120 & 238 & 5.80 & 1 \\
\hline Akuric board & 167 & 125 & 247 & 5.50 & 48.5 \\
\hline Al (standard absorber) & & 14.5 & 28.5 & & 1 \\
\hline
\end{tabular}

た。標制にした測定器は，Model 576 (直径 $47 \mathrm{~mm}$ ， 長さ $114 \mathrm{~mm}$ ) である。Table 1 にサーペイメータの種 類と校正定数を示す。低エネルギー用龟耀箱型サーペ メータ（ICS-101 C 型）ではェネルギー特性は良く補 正の必要はない。しかし X 線回折装置からの X 線は， 線束が細くサーへイメー夕の有奻空面を十分カバーしな 、場合が多、ので，照射率測定には特に注意が必要であ る。Cutie Pie 型のサーヘイメータ（DRー130-1 型） では，半空閌の状態での校正定数を示してある。これは
空以外の部分が厚さ $3 \mathrm{~mm}$ のベークライトのため $8 \mathrm{keV}$ の $\mathrm{X}$ 線はほとんと遮蔽され，相対感度は約1/2になる。 GM 管型サーヘイメータでは，照射率の高、場合は測定 できないか，検出感度は極めて高いので漏洩線の㭘出に は適している。すなわち SM-110型では， $740 \mathrm{cpm*}$ が，TBS-103B型では，1,000cpmがそれぞれ $1 \mathrm{mR} / \mathrm{h}$ に相当する。しかしェネルギー特性は悪く， $\mathrm{mR} / \mathrm{h} て ゙$

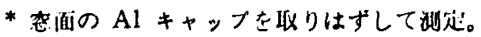


西 健雄, 山田典一, 南

目盛ってある SM-110型** では相対感度が1/4に娍し ている。

\section{3. 各理物贸の X 線に対する遮蔽勃果}

身近にある材料や実駼衣等について，銅ターゲットを 用いて $8 \mathrm{keV} の$ 低エネルギーX 線に対する遮䑤奻果 （減弱曲線）を調へ，それを基にして吸収係数を求め た。

アルミニウムの標洀吸収板セットを用いて，8keV X 線に対して得られたアルミニウムの減弱曲線を Fig.3に 示した。Fig.4は実駼に用いた各物留の娍弱曲線（百 分本表示）を示したものである。Table 2 に実婜に使用

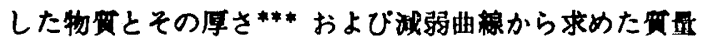

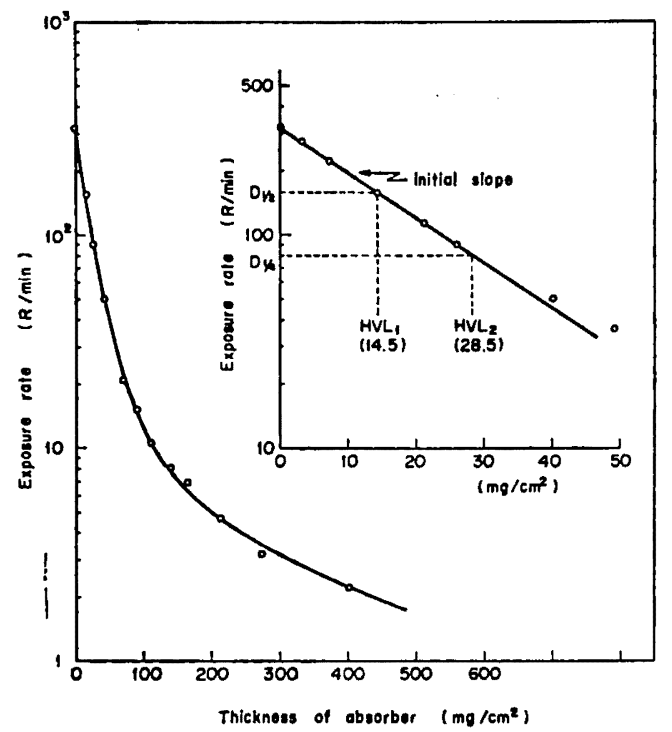

Fig. 3 Attenuation curve of $8 \mathrm{keV}$ X-rays for aluminium standard absorber

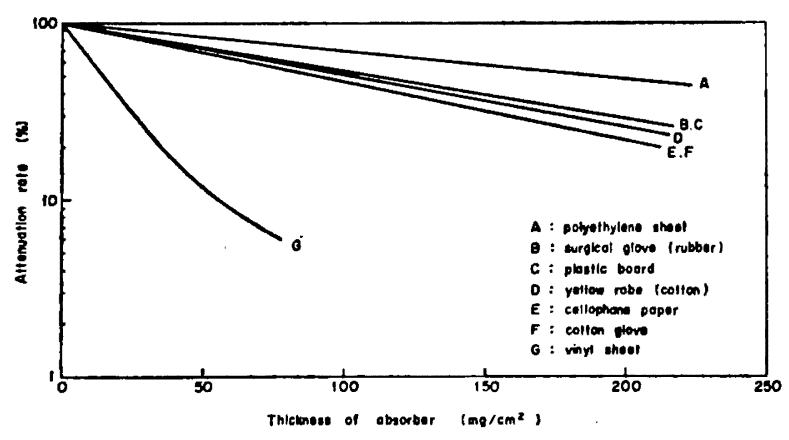

Fig. 4 Attenuation curve for various absorbers

** Ra 源慗で校正してある。

*** 叶量にはメトラ直示天秤 (Metter Bー6) を用いた。
员太郎，長谷川圭佑，三尹規生

吸収保数とアルミニウム当贯を示す。衰中の庶さは，実 験に使用した物贺 1 枚についての厚さを $\mathrm{mg} / \mathrm{cm}^{2}$ で表 わしたものである。变量吸収係数 $(\mu \mathrm{m})$ は，各娍弱曲 線の Initial slope から第 1 ，第 2 半価首 $\left(\mathrm{HVL}_{1}\right.$, $\left.\mathrm{HVL}_{2}\right)$ を求め, $\mu \mathrm{m} \cdot \mathrm{HVL}=0,693$ の式を用いて即算 したものである。これによって得られたアルミニウムの 繁吸收係数は $48.5 \mathrm{~cm}^{2} / \mathrm{mg}$ であり， B. D. Cullity2) の值と一致している。普通高エネルギー $\mathrm{X}$ 線に対して は銅当虽や鉛当量が，低エネルギーX 線に対してはフ ルミニウム当量またはセロファン当氞》が用いられるが ここでは正碓に計吾されていろアルミニウム吸収板をも とにアルミニウム当量を求めた。Fig. 3に示した。 Intial slope は, $8 \mathrm{keV}$ の特性 $\mathrm{X}$ 線の娍弱から得られ たものである。吸収層が厚くなるとともに減弱曲線が Initial slope の㑯料からはずれるのは，制動放射によ ろ寄与である。

実験に用いたヒニールとボリエチレンシートでは, 遮 蔽効果はビニールが極めて大きい。ボリエチレンは笼絭 と水素から成っていろが，実駼に用いた垭化ビニールは これらの 元素の他に埴素が 重量比で約 $60 \%$ 合まれてお り，その吸收が奇与するためと考える。また他に安定用 として鉛, カトミウム, アンチモン等が1〜2\%㙁化ヒニ 一ルには含まれている。 RI 取扱用手袋のゴムでは, 半 価層は $110 \mathrm{mg} / \mathrm{cm}^{2}$ で，手袋の約 6 枚に相当する。布手 袋では半価層は 7 枚 $\left(92.8 \mathrm{mg} / \mathrm{cm}^{2}\right)$ である。ゴム手袋 および布手袋はいずれも1枚では約 10\%減少するだけ で，低エネルギーX線であってもあまり防護の役目を果 さない。黄色実駼衣の半価層は, 約 4 枚 $\left(104 \mathrm{mg} / \mathrm{cm}^{2}\right)$ で, 1 枚の娍弱は17\%である。

\section{IN .䊅 語}

この種の X 線回折装置の放射線管理を行なうにあ たっては，低エネルギー用サーヘイメータを持に用意 しなくても，手近にあるサーベイメータを利用して十 分測定できることがわかった，漏洩線の検出には，榆 出感度の高、GM 管型サーヘイメータが有效であり， また照射事の測定には， $\beta$ 線測定用空を眮けて用いる ことにより，エルネギー特性の良いCutie Pie 型サ 一ベメータが有奶である。ただし，細いヒーム状の $\mathrm{X}$ 線による被噒線量を娜定する場合は，ビームの澌定 器への入射状悲を考鬼しながら測定しないと，遇小評 価をする他険がある。

実際の $\mathrm{X}$ 線防護になると，数 $\mathrm{kV}$ 程度の低エネルキ 一X線では,こく海い $1 \mathrm{~mm}$ 程度の鉛で十分遮蔽できる ので，見掛けの厚いコム手袋等を二重に重ねておけば， 
たとえ諆って1次 X 線束の内に手を入れても大文夫の ように安易に考えがちであるが，我々の測定ではこれは あまり遮蔽奻果が認められなかったので，やはり取扱い の際は作業者が操作に十分な注意を払う必要がある。

本実験に際して助言を与えられた当䂨究所安全管理課 長福田整司氏といろいろと御援助下さった照射 3 課村网 進氏ならびに利用開発室の川上泰氏に感謝致します。

\section{Appendix}

\section{放射線管理における低エネルギーX線測定と 被显線量評価}

$\gamma$ 線用サーへイイメータを用いて $\mathrm{X}$ 線回析装置から発 生する低エネルギー $\mathrm{X}$ 線の測定を行なう場合に, 問题 となる測定值の信頼性を示寸指㮛 $(\mathrm{H})$ についてのへる。

現在使用している奄雄箱型サーヘイメータの奄離箱は Fig. 5 (a)，(b) に示寸よjに，比較的椎方向に長い電 㫿箱であるが, Aloka・ICS-101 C 型は树方向に短か く低エネルギー X 線の測定に有奻な粠造になっている。 一般に電離箱型サーベイータで X 線測定を行なう場 合, 龟觹箱の入口における X 線エネルギーフルエンス $Q_{0}$ と，奄噰箱の出口における X 線エネルギーフルエン ス $Q_{0} \exp \left(-\mu \Lambda_{t} X\right)$ との比 $(H)$ か 1 に近くなけれ ばならない。X 線エネルギーが高い場合には $\mu \wedge$ かか小

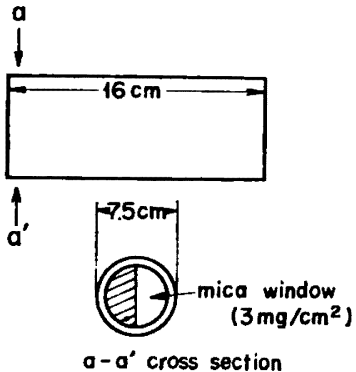

TEN DR-130-1

(a)

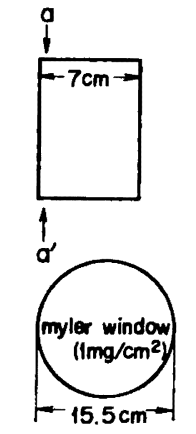

$a-a^{\prime}$ cross section

ALOKa ICS - $101 \mathrm{C}$

(b)
Fig. 5 Dimention of Chambers

さいので，電離箱が長くても電蹃箱内における X 線エ ネルギーの減弱は十分小さく $\mathrm{H}$ は1に等しい。したが って測定点（㫣飾箱の人口）における照射本を正しく示 すことになる。

$$
H=\frac{Q_{0}}{Q_{0} \exp \left(-\mu_{A}^{t} x\right)}=\frac{1}{\exp \left(-\mu^{A} t x\right)}
$$

ただし $Q_{0}$ : 電晟箱の入口におけるX 線エネルギー フルエンス $\left(\mathrm{erg} / \mathrm{m}^{2}\right)$

$\mu_{t}$ ：低エネルギー $\mathrm{X}$ 線に対する空刘の真 の吸収係数 $\left(\mathrm{cm}^{-1}\right)$

$x$ : 電觹箱の长さ $(\mathrm{cm})$

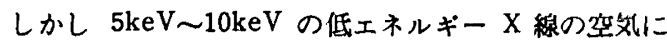
対する真の吸收保数は Table 31)に示すように非常に大 きい。電雄箱の長さが長い場合には H の值が 1 に近く ならず，したがって測定点（電離箱の入口）における照 射本を正しく示すことができず，単に電雄箱全体の容䅡 で平均化した照射率を示すことになる。それゆえ，低工 ネルギー $\mathrm{X}$ 線の照射率を正しく求めるために， $\boldsymbol{B}$ 線の 場合と同棣に外捚雨離箱が必要になる。X 線回折で主に

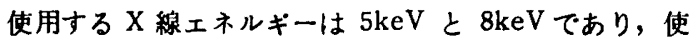
用している範離箱の長さは $16 \mathrm{~cm}$ (TEN) と $7 \mathrm{~cm}$ (Alo ka)である。したがってこれらのエネルギーに対して

Table 3 True absorption coefficient and H.V.L. for air and water')

\begin{tabular}{|c|c|c|c|c|c|}
\hline X-ray energy & \multicolumn{2}{|c|}{ air $^{*}$} & \multicolumn{2}{|c|}{ water } \\
\hline$\left(\mathrm{A}^{\circ}\right)$ & $(\mathrm{kev})$ & $\begin{array}{c}\bar{\mu}_{i}^{A} \\
\left(\mathrm{~cm}^{2} / \mathrm{g}\right)\end{array}$ & $\begin{array}{c}\text { H.V.L } \\
(\mathrm{cm})\end{array}$ & $\begin{array}{l}\vec{\mu}_{t}^{W} \\
\left(\mathrm{~cm}^{2} / \mathrm{g}\right)\end{array}$ & $\begin{array}{c}\text { H.V.L } \\
(\mathrm{cm})\end{array}$ \\
\hline 0.6 & 20.7 & 0.75 & 720 & 1.0 & 0.69 \\
0.7 & 17.7 & 1.3 & 410 & 1.5 & 0.46 \\
0.8 & 15.5 & 1.6 & 340 & 2.1 & 0.33 \\
0.9 & 13.8 & 2.1 & 260 & 2.8 & 0.25 \\
1.0 & 12.4 & 2.6 & 210 & 3.8 & 0.18 \\
1.5 & 8.26 & 8.7 & 62 & 12 & 0.058 \\
2.0 & 6.2 & 21 & 26 & 28 & 0.025 \\
2.5 & 4.96 & 39 & 14 & 51 & 0.014 \\
3.0 & 4.14 & 63 & 8.5 & 85 & 0.0082 \\
3.5 & 3.54 & 96 & 5.6 & 129 & 0.0054 \\
4.0 & 3.10 & 140 & 3.8 & 191 & 0.0036 \\
4.5 & 2.76 & 200 & 2.7 & 261 & 0.0027 \\
5.0 & 2.48 & 270 & 2.0 & 347 & 0.0020 \\
6.0 & 2.07 & 430 & 1.2 & 590 & 0.0012 \\
\hline
\end{tabular}

* $760 \mathrm{mmHg}, 0^{\circ} \mathrm{C}$

Tab!e 4 Figure of merit $\mathrm{H}$ for measurement of low energy $\mathrm{X}$-rays

\begin{tabular}{|c|c|c|}
\hline $\mathrm{keV}$ & $\begin{array}{l}\text { TEN. ionization cha- } \\
\text { mber. (length 16cm) }\end{array}$ & $\begin{array}{l}\text { Aloka. ionization cha- } \\
\text { mber. (length 7cm) }\end{array}$ \\
\hline 8 & 1.2 & 1.1 \\
\hline 5 & 2.2 & 1.4 \\
\hline
\end{tabular}


(1) 式の H の值を求めてみると，Table 4に示すょう になる。Victoreen のチェンバー 576 を標制にして $8 \mathrm{keV}$ の X 線で Aloka の㫣離箱を校正した結果, 校正 定数1.05となり良い值を示した。このような值を示すこ とは Table ムからも推測できる。また Aloka の電畋 箱の $8 \mathrm{keV}$ の校正值を $5 \mathrm{keV} の \mathrm{X}$ 線測定に利用すると 多少俱差が生じろであろうが，Table 4 から推測して実 用上問題はないと考える。TEN の䉓雄箱は低ェネルギ 一X線測定に不都合な入射密になっているので校正值は よくない。なおこれらの電踓箱型サーへイメータによる 低エネルギーX 線測定は, plane intensity の測定に近 いものであるから，敛乱X線の測定なとをを行なうときに は照射事の評価に注意すへきである。

次に人体の軟組耧を水と仮定した场合の低エネルギー $\mathrm{X}$ 線による被瞵線諻評価は次のようになる。低エネルキ 一 X 線の組維内における娍弱は非常に强く $8 \mathrm{keV} の \mathrm{X}$ 線は顿租栈の $3 \mathrm{~mm}$ で䄪 $1 / 32$ に娍弱する (Table 3 參 照)。したかっってß線によろ被潇線量計算と同しように 汁算した方が良、5)。X 線の平行ビームが組䋐に垂直に 入射していると考元租糡中では指数関数的に減弱してい ると仮定し，エネルギーフルエンスの組紻内での娍少を $\Delta Q$ とすると，組織のある梁さ $x\left(\mathrm{~g} / \mathrm{cm}^{2}\right)$ の点における 吸収線量 $D_{x}$ は次の式で示される。

$$
\begin{aligned}
& D_{x}=\frac{\Delta Q}{\Delta x}=\frac{Q_{0} \exp \left(-\overline{\mathrm{L}} T_{t} x\right)-Q_{0} \exp \left\{-\overline{\mathrm{u}} T_{t}(x+\Delta x)\right\}}{\Delta x} \\
& \simeq Q_{0} \bar{\mu} r_{t} \exp \left(\bar{x} T_{t} x\right)(\mathrm{erg} / \mathrm{g})
\end{aligned}
$$

買太郎，长谷川圭佑，三戸規生

$\Delta x:$ 組䄉内の $x$ の点における微小距離

$\left(\mathrm{g} / \mathrm{cm}^{2}\right)$

電解箱型サーベイメータによる測定值を $\boldsymbol{R}_{\mathbf{0}}$ (レント ゲン)とすれば， $Q_{0}$ は次のように示される。

$$
Q_{0}=R_{0} \frac{87}{\bar{\mu} A_{t}}\left(\left(\mathrm{erg} / \mathrm{cm}^{2}\right)\right.
$$

ただし， 収係数 $\left(\mathrm{cm}^{2} / \mathrm{g}\right)$ である。(2)および（3）式より吸收線 韋をラド単位で求めると次式となる。

$$
D_{x} \simeq 0.87 \frac{\bar{\mu} T_{t}}{\bar{\mu} A_{t}} R_{0} \exp \left(i \bar{t} T_{t} x\right)
$$

たとえば，クロムターゲットを使用して $5 \mathrm{keV}$ の特性 $\mathrm{X}$ 線を取扱っている人が，電雄箱型サーベイメータで測 定して $600(\mathrm{R} / \mathrm{h})$ の X 線ビームで 1 分間被睡したとす ると，不感層淔下における被嫘線量 $D_{X}$ は (4) 式より次 のように求められる。

$$
D_{x}=0.87 \times \frac{51}{39} \times 10 \times e^{-51 \times 7 \times 10-3}=8 \mathrm{rad}
$$

QFを1とすれば 8 rem と考えて艮い。

$$
\text { 考女献 }
$$

1）小西恵美子, 小野道美, 安斉有郎, 吉沢康雄；回 折用 X 線装置の放射線管理計画に関寸る考察, 保健物理，2，57 (1967)

2) B.D. Cullity（松村源太郎祄）："X 線回折要論", P 471，アグネ社 (1966)

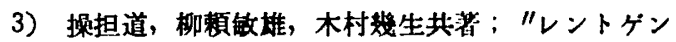
の取扱方" P 162 㻃華房 (1960)

4）高灀喜久雄；“X 線物理実駼法"，P 124，丸蓄 (1641)

5）南 福田整司；保健物理，1，20（1966）

\section{秋の原子力学会分科会について}

日本原子力学会誌 12 巻 5 号 298 頁で既に御存知と存し ますか，秋の保健物理分科会が下記の 要領で開かれま す。第 6 回保物発表会も計画か発表されておりますか， この分科会も会貝皆さんのお役に立つように願っており ます。

記

日時 昭和 45 年 9 月 24 - 25 日

場所 東海大学 佐々木校舍 